\title{
Interrogating the interactions between myeloid derived suppressor cells and cancer stem cells in glioblastoma
}

\author{
Balint Otvos ${ }^{1,3^{*}}$, James Finke ${ }^{2}$, Michael Vogelbaum ${ }^{3}$, Justin D Lathia ${ }^{1,3}$ \\ From Society for Immunotherapy of Cancer 28th Annual Meeting \\ National Harbor, MD, USA. 8-10 November 2013
}

Cellular and molecular regulation of the immune system is exquisitely controlled in the brain and is disrupted in neoplasia. Despite accumulation of immune cells in the tumor microenvironment, glioblastoma (GBM) growth persists while the mechanisms suppressing immune function remain largely unknown. Myeloid derived suppressor cells (MDSCs) are a heterogeneous class of immune cells responsible for immunomodulation through the suppression of cytotoxic T-cells. These populations are elevated in the peripheral blood of GBM patients, but their roles within the GBM microenvironment are uncharacterized. Through immunofluorescence analysis, we identified MDSCs within human GBM specimens, suggesting an immunosuppressive phenotype marked by arginase 1 (Arg1) staining. We have also observed colocalization between MDSCs and GBM cancer stem cells (CSCs) in both human tissues and mouse xenografts, leading to the hypothesis that CSCs recruit MDSCs to the tumor microenvironment, promote their survival, and that MDSCs are responsible for the immune-evasive properties of CSCs (Fig. 1A). Intracranial (IC) injections of CSCs into mice have led to GBM formation, expansion of the Arg1-producing MDSCs within the marrow of GBM-bearing mice, and increased levels of MDSCs within the GBM microenvironment (Fig. 1B-E). CSC conditioned media promoted decreased apoptosis and increased Arg1 production of murine bone marrow derived MDSCs. Our results suggest a critical role by which GBM is able to promote immunosuppression through the recruitment of MDSCs and a novel paradigm of immunomodulation by CSCs in GBM.

${ }^{1}$ Cellular and Molecular Medicine, Cleveland Clinic Foundation, Cleveland, $\mathrm{OH}$, USA

Full list of author information is available at the end of the article

\section{Authors' details}

${ }^{1}$ Cellular and Molecular Medicine, Cleveland Clinic Foundation, Cleveland, $\mathrm{OH}$, USA. ${ }^{2}$ Immunology, Cleveland Clinic Foundation, Cleveland, OH, USA. ${ }^{3}$ Brain Tumor and Neuro-Oncology Center, Cleveland Clinic Foundation, Cleveland, $\mathrm{OH}$, USA.

Published: 7 November 2013

doi:10.1186/2051-1426-1-S1-P268

Cite this article as: Otvos et al:. Interrogating the interactions between myeloid derived suppressor cells and cancer stem cells in glioblastoma. Journal for ImmunoTherapy of Cancer 2013 1(Suppl 1):P268.

Submit your next manuscript to BioMed Central and take full advantage of:

- Convenient online submission

- Thorough peer review

- No space constraints or color figure charges

- Immediate publication on acceptance

- Inclusion in PubMed, CAS, Scopus and Google Scholar

- Research which is freely available for redistribution

\section{() Biomed Central}




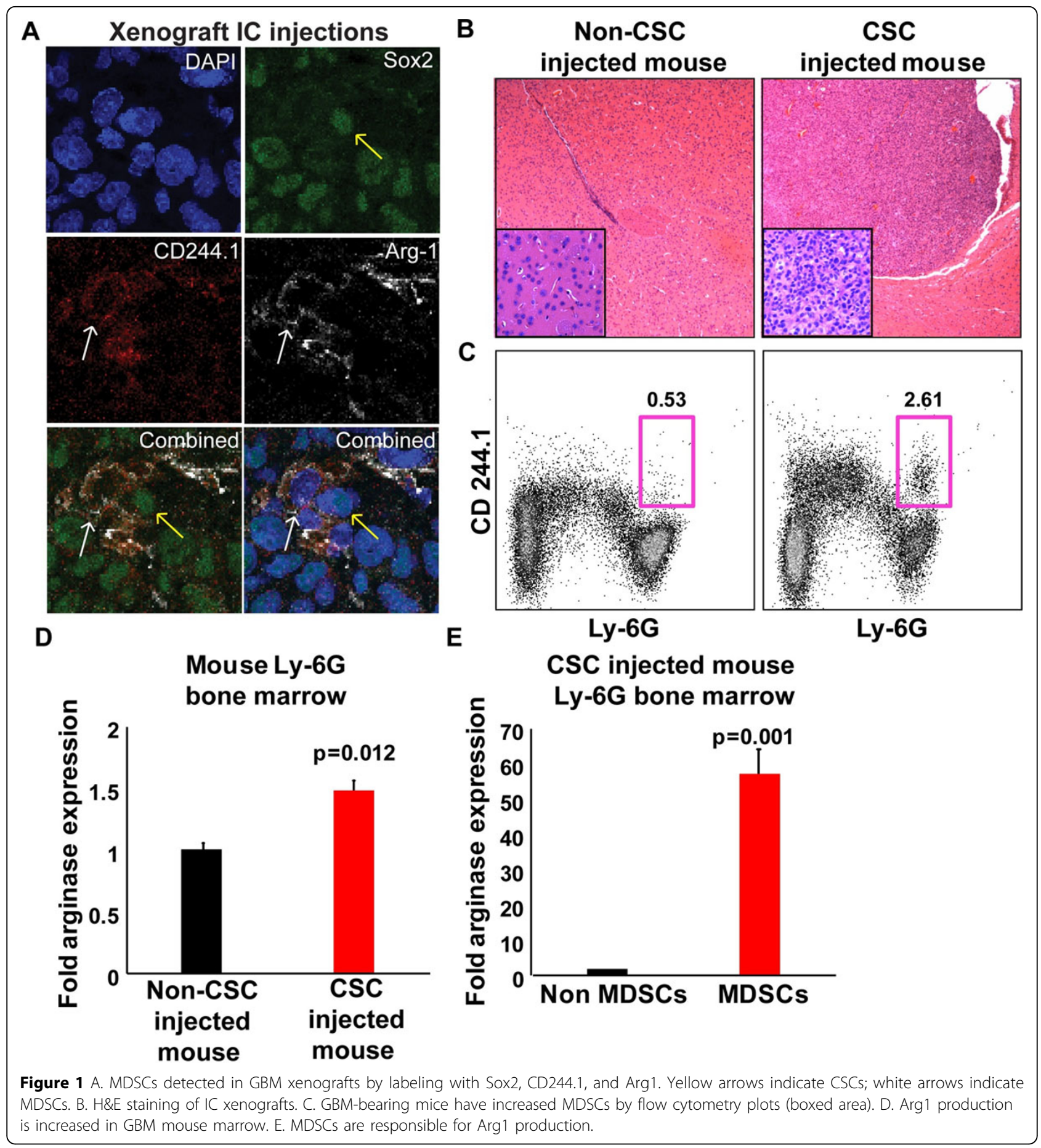

